\title{
Mafia markers: assessing organized crime and its impact upon societies
}

\author{
Jan Van Dijk
}

Published online: 9 October 2007

(C) Springer Science + Business Media, LLC 2007

\begin{abstract}
This study develops a causal model of the independent effect of organized crime, rule of law, and corruption on national wealth. To measure the level of organized crime a Composite Organized Crime Index (COCI) is constructed combining data on the perceived prevalence of organized crime, unsolved homicides, grand corruption, money-laundering and the extent of the black economy, drawing on the World Economic Forum's annual surveys among CEOs of larger companies, the Merchant International Group's assessments of investment risks in 150 countries, studies by the World Bank Institute, and official crime statistics. The findings of the explorative analysis show that a political strategy of tolerating activities of local criminal groups in the hope of beneficial effects on the wealth of a nation is unlikely to bring the expected results. Although some types of organized crime may bring in significant revenues, tolerating Mafia-type activities implies letting the Trojan horse of racketeering and grand corruption into the walls of government.
\end{abstract}

Keywords Mafia markers · Organized crime $\cdot$ Rule of law

\section{Introduction}

There is a need of more and better statistics on organized crime and grand corruption for both academic purposes and strategic planning in the fight against transnational organized crime. Strenuous efforts are therefore made by international organizations such as Europol and the United Nations Office on Drugs and Crime to harmonize official data of police and courts on transnational organized crime and corruption. It seems doubtful that such administrative data will ever produce useful indicators of

J. Van Dijk $(\bowtie)$

Pieter van Vollenhoven Chair in Victimology, Human Security and Safety, University of Tilburg,

Tilburg, The Netherlands

e-mail: Jan.vanDijk@uvt.nl 
the level of these types of crime across countries. In a global context numbers of arrests or convictions for involvement in organized crime are likely to reflect police performance rather than the true extent of criminal activity. In countries where organized crime is most prevalent, investigations into such crimes will be hampered by police corruption and political interference in prosecution and sentencing. Fewer investigations or prosecutions of organized crime will be initiated or successfully completed. Low rates of court cases on corruption or organized crime in a country may point to high rather than low prevalence of such types of crime. High numbers of arrests or convictions for corruption may indicate a comparatively low prevalence of such crimes due to better policing (Lambsdorff 2006). Police-based information on levels of organized crime will often be misleading. In the field of complex crimes, statistics of police-recorded or court-recorded crimes are a source of disinformation. The case of measuring levels of crime independently of the police is even stronger regarding organized crime and corruption than regarding common crime.

It is now generally acknowledged in criminology that the level of common crime across countries can be successfully estimated through standardized victimization surveys among the public (Van Dijk et al. 1990; United Nations 1999; Kury 2001; Nieuwbeerta 2002; Lynch 2006). Standardized survey research among samples of the public has opened new windows of opportunity for comparative crime measurement. In this article an attempt will be made to develop a similar alternative measurement of organized crime that can be used for statistical analyses of its correlates and impact.

\section{Diagnosing organized crime with the use of statistical "markers"}

The first requirement of measuring organized crime in an international context is agreement on its definition (Von Lampe 2004). Although definitions in national law show great variation, criminologists describe organized crime as criminal activities for material benefit by groups that engage in extreme violence, corruption of public officials, including law enforcement and judicial officers, penetration of the legitimate economy (e.g. through racketeering and money-laundering) and interference in the political process (Kenney and Finckenauer 1995; Levi 2002). These elements are not only incorporated in anti-Mafia laws of some countries, including the USA, Italy and Hungary (Fijnaut and Paoli 2004) but are also used as operational definitions by the European police community (Levi 2002).

Since ordinary households are not directly victimized by organized crime, victimization surveys cannot be used as vehicle to measure this phenomenon. But there seems to be no a priori reasons why the extent of organized crime as defined by criminologists could not be measured cross-nationally by interviewing groups of the population that are exposed to some of its defining traits. One of the most common types of organized crime is racketeering including the collection of protection money from businesses. Through victimization surveys among business executives reliable information can be collected on the extent of extortion practices in business communities in different countries (Van Dijk and Terlouw 1996). Since 1997 the World Economic Forum has carried out annual surveys among CEOs of larger 
companies to identify obstacles to businesses. These surveys include a question on the prevalence in the country of organized crime defined as "Mafia-oriented racketeering, extortion". Data are available on the prevalence of organized crime according to business executives of 102 countries. An analysis was conducted of the results from the seven rounds of WEF surveys conducted between 1997 and 2003. National scores proved to be very consistent across years. To reduce sampling error, the scores of the annual surveys were averaged. The resulting mean scores for $1997-$ 2003 are based on sample sizes of 500 or more. The national scores reflect the perceived prevalence of organized crime in the period 1997 to 2003 according to business executives.

Another source of cross-national data on perceived organized crime are risk assessments made by international consultancy companies. The London-based consultancy company Merchant International Group assesses investment risks in over 150 countries including the prevalence of different types of organized crime. The risk assessments concerning organized crime from MIG were found to be strongly correlated to the perceptions of business executives of the WEF surveys. In order to facilitate further statistical exploration, a composite index was constructed based on the averaged rankings of countries on the WEF surveys of 1997 to 2003 and the assessments of organized crime prevalence of MIG. $^{1}$ The resulting Organized Crime Perception Index (OCPI) refers to the level of different types of organized crime activities such as extortion and drugs, arms and people trafficking as perceived by potential victim groups and/or independent experts.

The widespread perception among business executives and risk consultants that organized crime activities are relatively common in a country provides by itself no conclusive proof that this is actually the case, but it certainly provides ground for further examination. It can be regarded as a first statistical "marker" of organized crime presence. What other proxy indicators of organized crime could be used? As mentioned above, instrumental violence, corruption of public officials and moneylaundering are regarded as other defining characteristics of organized crime. It is indeed hard to imagine a country where organized crime is rampant without significant amounts of these three Mafia-related phenomena. Statistical indicators were selected for the prevalence of each of these three defining characteristics of organized crime. Police-recorded homicides can be roughly divided into emotional attacks on intimates and cool-blooded killings executed by organized crime. The perpetrators of the first category are in most cases arrested. The perpetrators of the second category are not. To develop a proxy measure of 'mob-related violence', rates of unsolved homicides were calculated by deducting numbers of convictions for homicide from the numbers of police-recorded homicides. ${ }^{2}$ The resulting country rates of unsolved murders per 100,000 population were found to be fairly strongly correlated to the national scores on the Organized Crime Perception Index $(r=0.57$; $n=63 ; p<0.05)$. Similarly a proxy indicator of 'high level corruption' was derived from data sets of the World Bank Institute and indicators of money-laundering and

\footnotetext{
${ }^{1}$ For an explanation of the methodology of the index, please consult Kangaspunta et al. (1998) or Van Dijk (2007).

${ }^{2}$ Both types of data were drawn from the crime and criminal justice surveys of UNODC (Shaw et al. 2003).
} 
the extent of the black economy were taken from the World Economic Forum surveys among business executives. All three indicators proved to be strongly correlated to the scores on the Organized Crime Perception Index as well. These findings support the construction of a composite organized crime index combining the five interrelated proxy indicators: perceived prevalence of organized crime, especially racketeering, unsolved homicides, grand corruption, money-laundering and the extent of the black economy (cronbach's alpha vs. 82).

An important strategic advantage of the resulting Composite Organized Crime Index is the incorporation of at least one objective measure of organized crime activity, the rate of unsolved homicides according to official administrations. Scores on this composite index cannot be dismissed by governments as being based on 'just perceptions'. The scores are corroborated by the official 'body counts' of national police authorities as reported to the United Nations through the Crime Surveys of UNODC.

Table 1 depicts the mean scores on the Composite Organized Crime Index of world regions. To allow a more detailed diagnosis of regional problems with organized crime, the picture presents both the absolute scores of regions on the composite index as well as the rank numbers on the five source indicators used.

The ranking of regions according to the composite index and those according to the five constituting indicators show a high degree of consistency. Outliers are the

Table 1 Regional mean scores on composite organized crime index (COCI) and data on source indicators: perceived organized crime prevalence, grand corruption, money-laundering, extent of shadow economy and the rates of unsolved murders per 100,000 population

\begin{tabular}{|c|c|c|c|c|c|c|}
\hline & $\begin{array}{l}\text { Average of the } \\
\text { composite } \\
\text { organized } \\
\text { crime index }\end{array}$ & $\begin{array}{l}\text { Organized } \\
\text { crime } \\
\text { perception } \\
\text { (rank) }\end{array}$ & $\begin{array}{l}\text { Informal } \\
\text { sector } \\
\text { (rank) }\end{array}$ & $\begin{array}{l}\text { Unsolved } \\
\text { homicides } \\
\text { (rank) }\end{array}$ & $\begin{array}{l}\text { High level } \\
\text { corruption } \\
\text { (rank) }\end{array}$ & $\begin{array}{l}\text { Money } \\
\text { laundering } \\
\text { (rank) }\end{array}$ \\
\hline Oceania & 33 & 1 & 1 & 1 & 2 & 1 \\
\hline West and central Europe & 35 & 2 & 2 & 2 & 4 & 3 \\
\hline North America & 44 & 4 & 4 & 4 & 6 & 4 \\
\hline East and south east Asia & 45 & 5 & 3 & 7 & 3 & 6 \\
\hline Central America & 50 & 4 & 13 & 3 & 8 & 13 \\
\hline Near and Middle East & 50 & 7 & 6 & 11 & 1 & 2 \\
\hline World & 54 & & & & & \\
\hline South Asia & 54 & 13 & 8 & 8 & 7 & 11 \\
\hline North Africa & 55 & 6 & 5 & 6 & & 5 \\
\hline East Africa & 55 & 11 & 9 & & 11 & 9 \\
\hline Southern Africa & 56 & 9 & 12 & 5 & 12 & 10 \\
\hline South America & 58 & 10 & 14 & 10 & 13 & 12 \\
\hline Southeast Europe & 58 & 14 & 10 & 12 & 9 & 14 \\
\hline West and central Africa & 60 & 12 & 11 & 15 & 5 & 8 \\
\hline East Europe & 70 & 16 & 16 & 14 & 14 & 16 \\
\hline $\begin{array}{c}\text { Central Asia and } \\
\text { Transcaucasian }\end{array}$ & 70 & 15 & & 13 & 15 & \\
\hline Caribbean & 70 & 8 & 15 & & 16 & 15 \\
\hline
\end{tabular}

Items and sources used: Organized crime perception (World Economic Forum, World Competitiveness Reports, Business Executive Surveys, 1997-2003; Merchant International Group 2004; BEEPS 1996); Money-laundering and Informal sector (World Economic Forum Business Executive Survey, 2004); High Level Corruption (Kaufmann et al. 2003), Unsolved Homicides (8th UN Survey on Crime and Justice 2002: www.UNODC.org). 
relatively high rank numbers on informal sector and money-laundering of Central America. Among the high crime regions, West and Central Africa shows relatively low rank number on homicides. The latter result could point to a shortcoming in the available statistics - homicide statistics for Nigeria are for example missing. It could also reflect that organized crime groups in the region are less prone to the use of extreme violence than elsewhere. Such deviations suggest that further research is needed before conclusions can be drawn.

\section{Country scores}

The combination of data from different sources allows the calculation of scores for a large number of individual countries. The rank numbers of countries for different indicators are mostly in the same range as the COCI rank but many deviations can be found. Deviations of single indicators from the COCI rank can point to specific features of organized crime in the country or to deficiencies in some of the measures. In both cases further research is indicated. In some cases the diagnosis at the country level can only be very tentative due to lack of sufficient information on the source indicators, notably on the numbers of unsolved homicides. At this stage of development, the utility of the index lies more in the possibility to carry out analyses of the macro correlates of organized crime than in the benchmarking of individual countries for policy purposes (Van Dijk 2007).

Figure $1 \mathrm{a}$ and $\mathrm{b}$ show the global and European maps of organized crime, based on the organized crime perception index.

As said, the rates of individual countries should not be taken at face value but be used as a basis for further enquiry. In Asia rates are the worst in parts of South Asia (Pakistan, Bangladesh). But also China and India are rated unfavorably (even more than Italy with its notorious problems in the south). In the international literature on organized crime India is rarely the focus of attention. Research on Chinese organized crime is mainly focussed on Chinese expatriates. Limited available research findings on homeland China point to collusion between corrupt communist party members and local gangs in remote areas (Zhang 2001). More research on the role of the organized crime-corruption in these two emerging superpowers seems warranted.

In Africa, Nigeria, Angola and Mozambique stand out with the highest scores. Nigerian organized crime activity in both the country and the region has been welldocumented (Shaw 2003; UNODC 2005). A detailed account of how organized crime threatens to penetrate state and businesses in southern Africa, notably in Mozambique, is given in Gastrow (2003). In Latin America, Haiti, Paraguay, Guatemala, Venezuela and Colombia show the highest scores. High scores are also observed in Jamaica. None of these scores will come as a surprise to informed readers.

Within Europe, organized crime prevalence increases diagonally from the north west to the south east, with levels being low in England and Germany, higher in Spain and Italy and by far the highest in Russia, Albania and Ukraine. The annual surveys of the World Economic Forum point at incremental improvements in some of the new members of the European Union. 


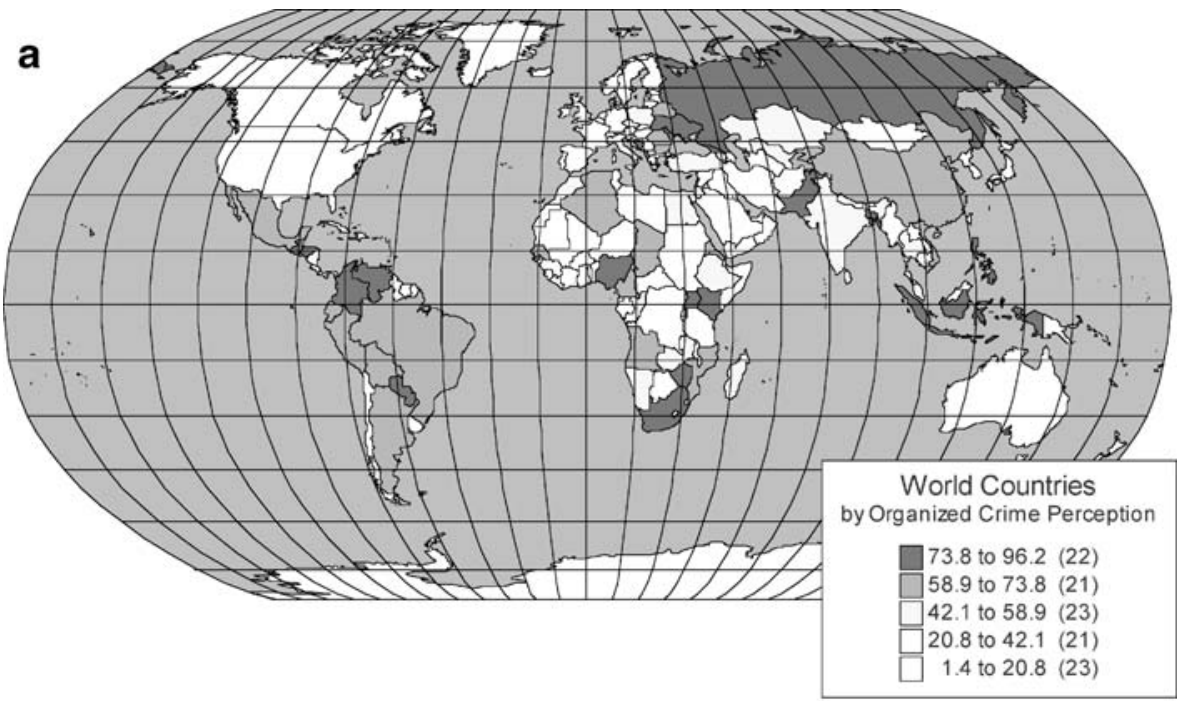

b

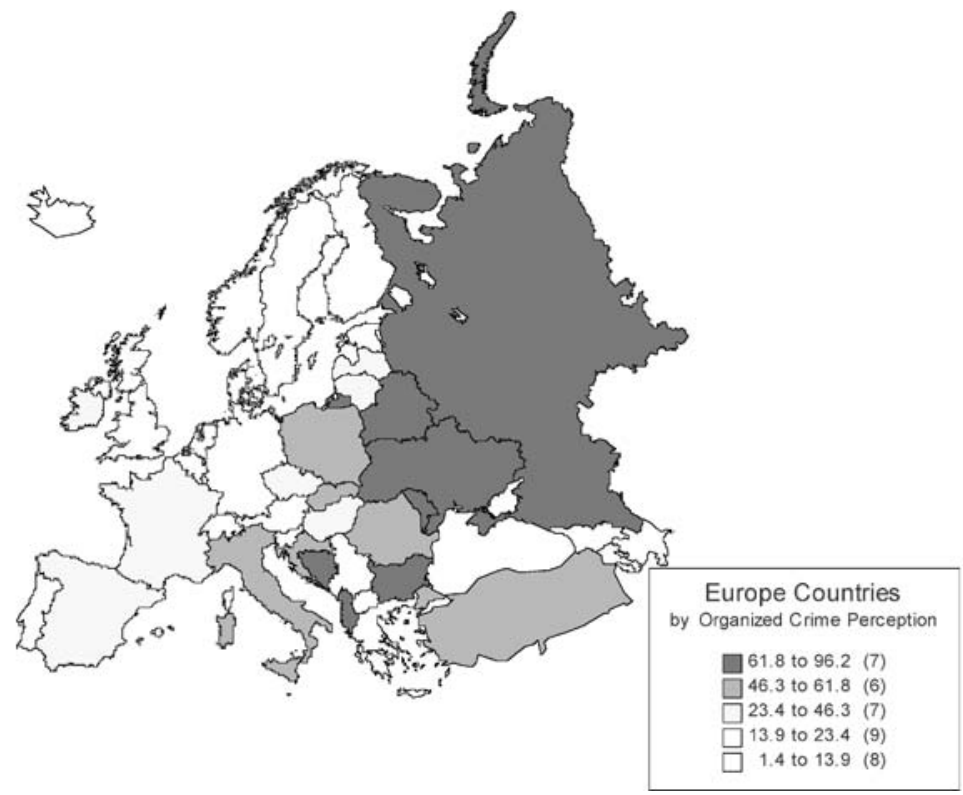

Fig. 1 a Global map with scores on organized crime perception index. b European map with scores on organized crime perception index

\section{Relationships between indicators of types of crime}

The primary utility of the organized crime indices lies, as said, in the possibility to carry out analyses of the macro correlates of organized crime. The first issue that seems worth exploring is whether the distribution of organized crime is similar to that of common crime across countries. Country rates for common crime are available from the third and fourth round of the International Crime Victim Survey 黑 Springer 
for 62 countries (Van Dijk 2007). Figure 2 shows a scatter plot of country values on the ICVS 1992-2000 and of national scores on the comprehensive organized crime index.

Countries placed in the upper right quarter are experiencing high levels of both organized and common crime (e.g. Colombia, Zimbabwe) and those in the bottom left corner show low scores on both types of crime (e.g. Switzerland, Botswana and Canada). A large number of countries are situated in neither of these two homogeneous groups. Their ranking on the level of common crime according to the ICVS is very different from their ranking in terms of organized crime.

The perceived prevalence of organized crime and the overall ICVS rates of victimization by common crime were found to be unrelated ( $r=0.02$, n.s.). The world map of organized crime differs fundamentally from that of common crimes. This result suggests that levels of common crime and of organized crime are determined by different factors at the macro level (Van Dijk and Nevala 2002). Common crime shows a clear downward trend in many Western countries since 1995 (Van Dijk 2007). There are no indications of similar declines in the level of organized crime or corruption (Lambsdorff 2006; Van Dijk 2007). Complex crimes should be analysed separately from volume crime. This finding confirms the need of developing separate indicators of organized crime and other complex crimes that can complement the results of the ICVS.

\section{Scatterplot of ICVS conventional crimes with organized crime index}

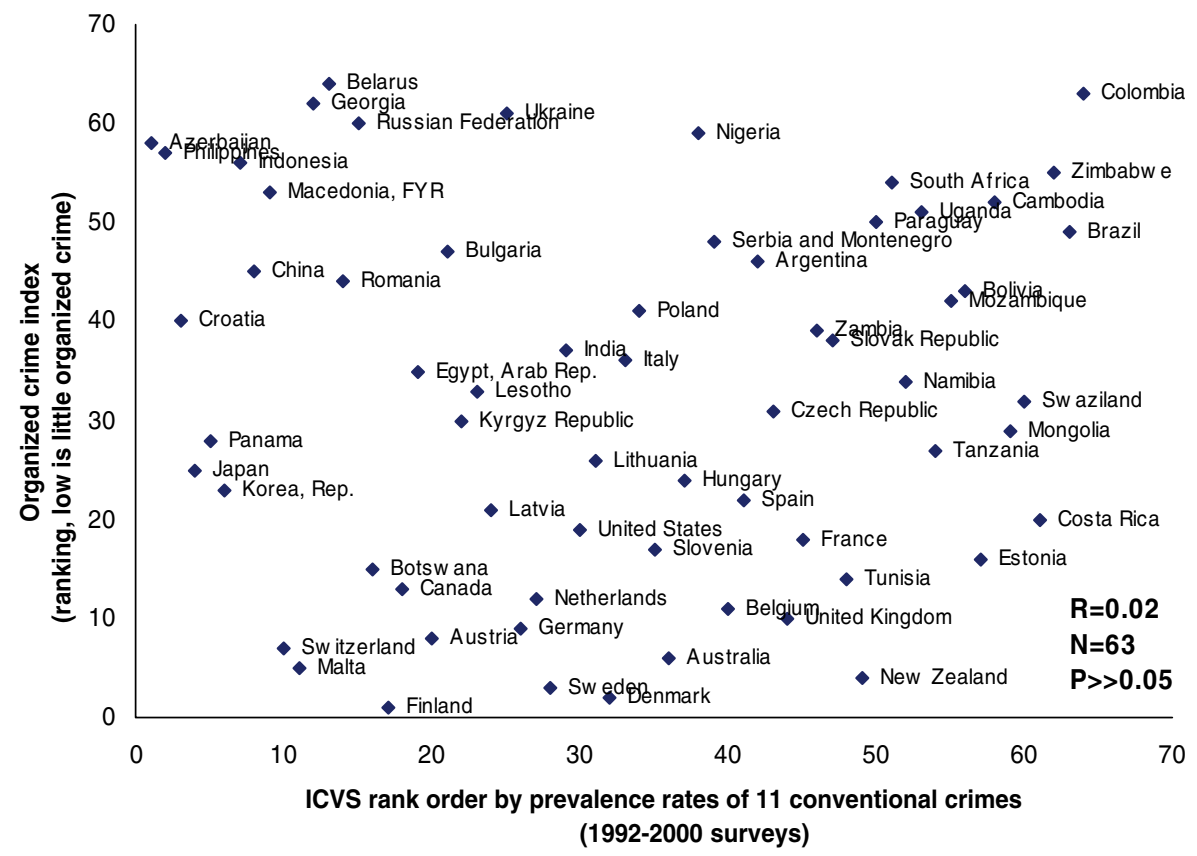

Fig. 2 International Crime Victim Survey and Organized Crime Index 


\section{Organized crime and the rule of law}

Elsewhere we have documented a strong link between a measure of police performance $^{3}$ and our indices of organized crime (Van Dijk 2007). The correlation coefficient between country scores on police performance and on the composite index of organized crime was very strong $(r=0.80 ; n=113 ; p<0.05)$. Where police forces operate more professionally, levels of organized crime tend to remain relatively modest. Case histories have revealed the crucial role of independent and competent prosecution services and judiciaries in tackling organized crime and corruption (Orlando 2001; Joly 2003). Special attention has therefore also been given to the relationship between the rule of law, including perceived independence of the judiciary, and the level of organized crime. For this purpose we used a composite measure of the rule of law developed by the World Bank Institute (Kaufmann et al. 2003). Figure 2 shows the relationship between country values on this index of the rule of law and our composite index indicating country levels of organized crime (Fig. 3).

Organized crime is more prevalent in countries where the rule of law is less well assured and vice versa. There are very few exceptions to this rule. ${ }^{4}$ The maintenance of the rule of law in the face of powerful Mafia groups requires first and foremost an independent, incorruptible judiciary. A separate analysis was made of the relationship between the organized crime index and the perceived independence of the judiciary specifically (WEF survey 2003). The two variables were found to be strongly correlated $(r=0.79)$. Multivariate analyses confirmed the relationship between the measure of judicial independence and levels of organized crime. Previous analyses showed furthermore that independence of the judiciary was the single most important predictor of the extent of organized crime (Buscaglia and Van Dijk 2003; Hung-En Sung 2004).

The critical factor determining the extent of organized crime is the quality of institutions responsible for the rule of law, including competent police services and independent courts complying with standards of professional integrity.

These results signify that criminal justice systems and organized crime groups impact negatively upon each other at the country level. High levels of organized crime rarely go together with strong policing and effective maintenance of the rule of law. Law enforcement and criminal justice probably play a significantly larger role in shaping the phenomenon of organized crime and related high-level corruption than in determining levels of volume crime. Well performing police services and independent, professional judiciaries seem to make a difference in controlling non-

\footnotetext{
${ }^{3}$ The Police Performance Index is a composite index incorporating information on the clearance rate of homicides, rate of victims of crime reporting to the police, satisfaction of victims and assessments of the public and the business community of police effectiveness in controlling crime (Van Dijk 2007).

${ }^{4}$ The rule of law index of the World Bank Institute comprises a large number of source indicators from different sources. Although one of the many indicators used is the WEF indicator of perceived organized crime that is also included in the Composite Organized Crime Index, this is unlikely to have had much effect on the correlation. Equally strong correlations have been found between the Organized Crime index and other indices of the rule of law not including the WEF indicator (Buscaglia and Van Dijk 2003). 


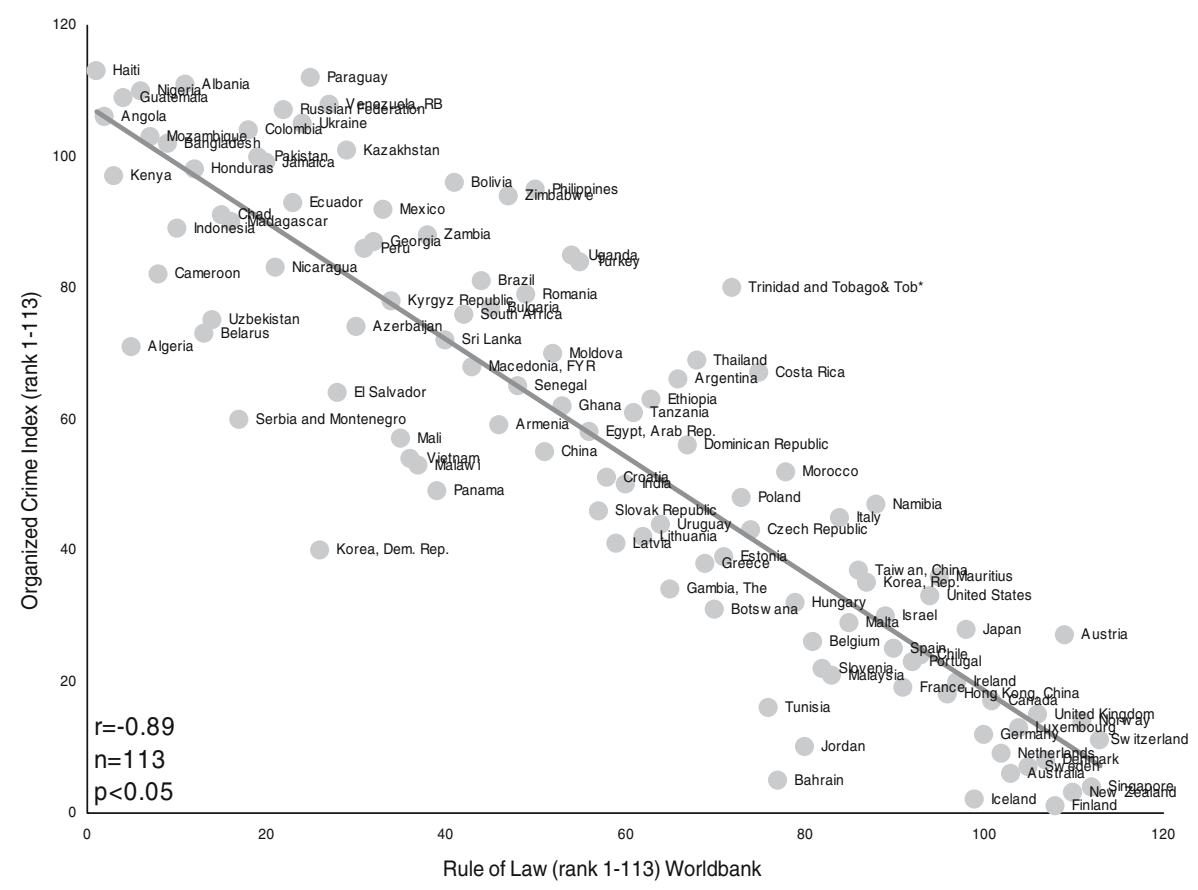

Fig. 3 Quality of Rule of Law (including independence of the judiciary) and Prevalence of Organized crime (Composite Organized Crime Index) per country

conventional crime. The role of the criminal justice system in fighting conventional crime has in the past perhaps been somewhat overrated (Waller 2006). But in the fight against complex crimes, including the organized crime-corruption nexus, the importance of criminal justice seems rather to be somewhat underrated. ${ }^{5}$

\section{Good governance, crime and national wealth}

In 'comparative economics' it is now more and more acknowledged that sound legal infrastructures, especially those governing 'property rights', are a primary determinant of economic performance (Acemoglu and Johnson 2003). ${ }^{6}$ Empirical studies have specifically demonstrated that various dimensions of 'good governance'

\footnotetext{
${ }^{5}$ In many countries, including The Netherlands, journalists specializing in organized crime reporting entertain close relations with key figures of local organized crime who feed them with information. One possible explanation of the lack of recognition of the role of police units and judiciaries in controlling organized crime may be that public perceptions are negatively influenced by media information discrediting police officers, prosecutors and judges.

${ }^{6}$ Acemoglu and Johnson (2003) found that institutions protecting institutions against expropriations by the government and powerful elites have a stronger effect on long term economic performance of countries than institutions enabling private contracts between citizens. Translated in conventional legal terminology this result would mean that public law, of which criminal law is part and parcel, is more important to economic performance of countries than private law.
} 
are prerequisites for sustainable economic development (Mauro 1996). Good governance, including the rule of law, has been found to be a critical success factor for sustainable development (Eiras 2003; Kaufmann et al. 2003). Some recent studies have confirmed the prominent role of protection of property rights and independent judiciaries for economic success (Barro and Sala-i-Martin 2004; Feld and Voigt 2003). In analyses of the World Bank Institute "state capture"-defined as undue influence on laws, policies, and regulation by special interest groups - and other manifestations of 'crony capitalism' or 'economic elitism', have been identified as root causes of institutional failure hampering development (Kaufmann 2004).

The strong statistical relationships between measures of 'governance' and economic growth or performance do not by themselves provide evidence that economic performance is driven by institutional quality. The causal effects might also be the other way around. There are several arguments why this alternative interpretation of the governance growth correlations is less plausible though. It should first of all be understood that good governance such as independent judiciaries does not require expenditures that only rich countries can afford. Independently functioning judiciaries depend more on sound legislation and political will than on availability of resources. On theoretical grounds it seems more likely that institutional quality causes wealth rather than that wealth causes institutional quality. There is also ample empirical evidence for the causal impact of governance on growth. Institutional failures have found to be not only correlated to current economic performance but also to future economic performance (Knack and Keefer 1995). In an empirical analysis of historical data on these issues Kaufmann and Kraay (2002) have refuted the notion that economic growth results in incremental strengthening of legal and institutional arrangements for 'good governance'. Their results suggest the absence of 'virtuous circles' in which higher revenues due to an economic boost and/or massive development aid automatically lead to further improvements in governance. Experiences in South America and Eastern Europe in particular show that higher levels of affluence do not necessarily translate into better governance. In periods of prosperity, established interest groups unduly influencing state policies may become even more entrenched because the stakes have become higher (Kaufmann 2004).

By the same token economic prosperity based on the discovery and subsequent rapid exploitation of rich natural resources such as oil or diamonds acts for many developing countries as an economic 'curse in disguise'. In many cases such resource dependency provokes the capture of the state by criminal elites and thereby stifles rather than promotes economic activity. ${ }^{7}$ The law and development literature provides several examples of countries where the possession of oil, diamonds or

\footnotetext{
7 "Wealthier countries of the OECD, as well as some in Eastern Europe find themselves in the 'good equilibrium' of relatively low tax and regulatory burden, sizeable revenue mobilization, good rule of law and corruption control, and [relatively] small unofficial economy', according to Johnson et al. (1998). 'By contrast, a number of countries in Latin American and the Former Soviet Union exhibit characteristics consistent with a 'bad equilibrium': tax and regulatory discretion and burden on the firm is high, the rule of law is weak, and there is a high incidence of bribery and a relatively high share of activities in the unofficial economy". To this salient conclusion one could add that, not coincidentally, organized crime is prominently present across the countries of Latin America and the former Soviet Union, as shown in Fig. 1a.
}

글 Springer 
other natural resources could have resulted in stronger institutions and subsequent lasting economic growth — as has been the case in Botswana-but where in reality the opposite has taken place. The revenues from resources are just as likely to generate rampant corruption and subsequent weakened institutions and diminished economic growth. Examples where such negative side effects seems to have prevailed are Angola, Nigeria, Zambia, Gabon and Venezuela (McMillan 2005).

The political implications of the finding that institutions are the driving forces behind economic development cannot be overestimated. An improvement in a country of, for example, 6 points on the Transparency International Corruption Perception Index, may increase GDP by more than 20\% (Lambsdorff 2004). The economic consequences of improved judicial infrastructures have also been quantified. When the quality of the rule of law is measured on a scale of 1 to 10 , every point of improvement generates between 0.2 and 0.8 additional economic growth per year (Barro and Sala-i-Martin 2004; Tornstensson 1994). If all African countries would succeed in building up judicial infrastructures that match those in South Africa or Botswana, many of them would soon be known as the "African lions".

In the discussion on "Mafia markers" reference was made to the close link between organized crime and corruption. The two phenomena are interlinked to such an extent that an indicator of grand corruption was included in our composite index of organized crime. In many parts of the world grand corruption and organized crime are two sides of the same coin. Surprisingly little attention is given in the law and economics literature just cited to the possible specific role of criminal justice and organized crime control in the institutional arrangements determining 'good governance' or the lack of it. As the final step in our analysis we will explore the links between the organized crime-corruption nexus, functioning law enforcement and justice systems and sustainable development. We will start with a theoretical cost-benefits assessment of organized crime and then revert to our metrics to analyse empirically the relationships between police performance, criminal justice, organized crime and economic performance.

\section{Costs and benefits of organized crime}

On the cost side, high levels of conventional crime, just as high levels of corruption, add to the immediate costs of doing business in a country. In one of its latest World Development Report, the World Bank sums up its evolving thoughts on the issue: 'crime...increases the cost of business, whether through direct loss of goods or the costs of taking precautions such as hiring security guards, building fences, or installing burglar alarm systems. In the extreme, foreign firms will decline to invest, and domestic ones will flee the country for a more peaceful locale' (World Bank 2005).

In the business executives opinion surveys of the World Economic Forum respondents are specifically asked to identify the most important obstacles to doing business in their country. Business executives in many countries list corruption and/or crime and violence as the most or second most important impediments to doing business in their countries (WEF 2003). This is often the case in countries with comparatively high scores on our index for organized crime prevalence. These opinions of business leaders working in high crime countries confirm the negative 
impact of organized crime on investments. In recent Investment Climate Surveys, 15\% of business executives reported that crime was a major constraint on investment $(29 \%$ of African executives gave this response; Brunetti et al. 1997). In some instances rampant organized crime may also deter foreign tourists from visiting the country. Security concerns are known to be among the most important considerations for selecting holiday destinations (World Tourism Organization 1997).

In Mafia-infested countries the costs of crime may go far beyond company losses to 'criminal leakage' and 'loss of customers'. In an important revision of the good governance theory, Kaufmann and Kraay (2002) have attributed the negative influence of high-level corruption on development to the intermediary factor of 'cronyism', the widespread interference of particular interest groups in rational decision-making in the economic domain. ${ }^{8}$ Infiltration in the legitimate economy and political process is, as discussed, a defining characteristic of Mafia-type organizations. If such 'crony capitalism' is indeed the main impediment of economic development, organized crime, as an especially entrenched type of 'cronyism', may well be at the heart of the governance-related economic problems of many countries. The Sicilian economy, for example, seems to have been seriously hampered by the reign of the Mafia and started to prosper only after the local Mafia bosses were put on the defensive through the maxi-trials and community mobilization (Orlando 2001). ${ }^{9}$ The experience with racketeering in New York also points to economic revitalization after the defeat of mob-related racketeering in several sectors of the local economy (Giuliani 2002).

Although organized crime groups are likely to be part of the problem of cronycapitalism, the overall impact of their criminal activities on the economy may not always be only negative. The production and trafficking of illicit commodities can result in considerable profits that are reinvested in the formal and informal economy of countries. Australian criminologist John Walker has estimated the total value of illicit drugs at wholesale value at $\$ 94$ billion (World Drug Report 2005). This is the equivalent of the export values of the agricultural commodities meat and cereals combined. At retail level the total value of illicit drugs is estimated at $\$ 322$ billion. Countries dominating the production and/or trafficking of illicit drugs will obviously benefit economically from their activities on these markets to some extent.

Narco dollars generated by the cocaine trade in the Americas are indeed known to have given a significant boost to national economies in Latin America in the 1990s. The total value of illicit drugs trafficking, annually injected into the Mexican economy in those years, has been estimated at over $\$ 25$ billion, or $6 \%$ of the country's GDP (Gonzalez-Ruiz 2001). In Tajikistan heroin trafficking revenues have been estimated as equivalent to 50\% of recorded GDP (Reuter et al. 2004). More recently, estimated revenues from drugs in Afghanistan vary from 30\% to as much as $60 \%$ of GDP. There can be no doubt that the heroin trade has fueled the Afghan economy as well as the economies of several transit countries since the defeat of the Taliban (UNODC, World Drug Report 2004). It is also widely assumed that

\footnotetext{
${ }^{8}$ In a case study of 'cronyism' in a Latin American country by Kaufmann and Kraay (2002), drug cartels and other organized crime groups are mentioned as key examples of the phenomenon.

${ }^{9}$ Moody Financial Certification, a financial analysis agency, upgraded its rating of the city of Palermo to Aa3, meaning excellent, in 2000.

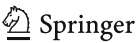


countries with offshore centers specializing in money-laundering facilitation reap significant benefits of such illicit financial services.

To empirically explore whether orgnanised crime hampers or spurs economic growth, the correlations between the composite measure of organized crime prevalence and indicators of economic development were analysed. The index for organized crime prevalence was found to have a moderately strong negative correlation to the Human Development Index $(r=0.49)$. The negative relationship between organized crime prevalence and GDP per 100,000 population was even stronger $(r=0.76)$. Figure 4 shows results in the form of a scatter plot.

The results depicted in Fig. 4 lend empirical support to the hypothesis that on balance organized crime is bad for the economy. In the case of cultivation, production or trafficking in illicit drugs organized crime may generate sizeable illegal profits but its prominence deters investment and impairs the capacity of governments to promote sustainable economic growth. Countries where organized crime groups are insufficiently reigned in, are economically in dire straits.

The fairly strong inverse correlation between organized crime and collective wealth merits further examination. As discussed above there are good reasons to assume that the inverse relationship between organized crime and wealth is mediated by governance factors such as police performance, the rule of law and corruption at the political level. In our view organized crime is negatively related to police performance and the rule of law and positively related to grand corruption. Effective policing and adherence to the rule of law at their turn contribute to sustainable

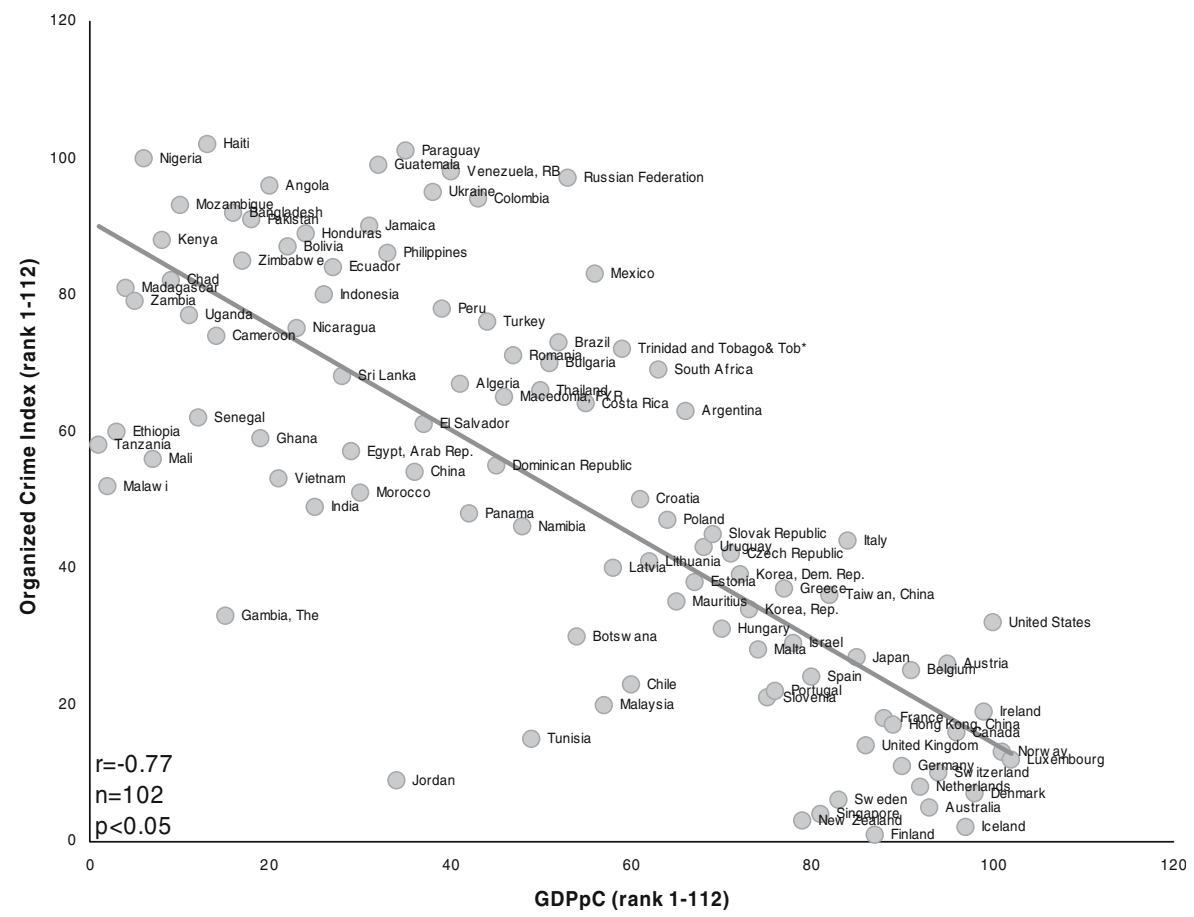

Fig. 4 Prevalence of organized crime (composite organized crime index) and GDP per capita 
economic development. Organized crime, then, will reduce economic development through its negative impact on policing and on the maintenance of the rule of law and through its positive impact upon corrupt practices at the highest level of government. Unclear seem the possible direct effects of organized crime on the economy. Although the inversed correlation between organized crime prevalence and economic wealth is strong, there are, as Fig. 4 shows, several outliers. The scatter plot shows that some countries with very high levels of organized crime nevertheless enjoy reasonably high levels of wealth (they are in the middle range for GDP rather than near the expected bottom end). This category of economically 'overperforming' high-crime countries includes Mexico, Russia, Venezuela, Colombia and Guatemala. Their relative wealth in spite of rampant organized crime/corruption might point to the positive direct effects of organized crime through crime-related economic injections. Although none of these countries enjoy the stably high GDP levels of the OECD countries, they might perhaps have been even poorer without their criminally acquired riches.

To explore the crimino-economic dynamics outlined above, we have first carried out a multiple regression analysis with GDP per capita as dependent variable. As independent variables we used country scores on the Organized Crime Perception Index, an index for grand corruption, developed by Buscaglia and Van Dijk (2003), the Rule of Law Index of the World Bank Institute and our index for Police Performance. The four independent variables combined explained $74 \%$ of the variance in GDP scores of countries. Table 2 shows results.

The strongest negative relationship was that between corruption and GDP (beta $=-0.551$ ). The rule of law indicator showed a positive correlation, independently of corruption $(r=0.363)$. Police performance also contributes, independently of the other factors, to wealth. Somewhat surprisingly for a variable with a strong negative correlation with GDP in a simple, two-dimensional model, organized crime was positively related to GDP, after controlling for the effects of corruption and rule of law (beta $=+0.256$ ).

One theoretically plausible model to explain these results assumes that organized crime leads to both lesser rule of law and weaker policing and to more corruption which all three lead to lower wealth. These indirect effects may fully explain the negative relationship between organized crime and wealth. The direct effect of organized crime on wealth, after controlling for the indirect effects, may disappear or even turn positive, as suggested by the outcome of the regression analysis.

In our final analysis, we looked at the independent effect of organized crime, rule of law, and corruption on wealth in a causal model representing the mechanisms just described. In this final analysis we used the Composite Organized Crime Index for

Table 2 Results of a stepwise multiple regression analysis with GDPpc as dependent variable (low-high)

\begin{tabular}{llll}
\hline Independent variables & Beta coefficients & Sig & Multiple $r$ \\
\hline Rule of law (low-high) & 0.363 & 0.008 & 0.781 \\
Org. crime (low-high) & 0.256 & 0.023 & 0.783 \\
Corruption (low-high) & -0.551 & 0.000 & 0.854 \\
Police (low-high) & 0.252 & 0.017 & 0.871 \\
\hline
\end{tabular}


organized crime, the corruption index of Transparency International for corruption and the Rule of Law Index of the World Bank. ${ }^{10}$ The model explains $65 \%$ of the total variance in the level of wealth and can thus be considered as fairly strong. In the model the negative relationship between organized crime and wealth does once again changed into a positive relationship in a multivariate analysis, controlling for the strong indirect, negative effects through rule of law and corruption. Figure 5 shows the results.

Although the precise values found in this analysis should not be taken at face value $^{11}$-replication studies (using other indicators) may result in slightly different outcomes - the results fully confirm the assumed dual impact of organized crime on the economy. On one hand organized crime goes together with compromised state institutions and rampant grand corruption. These factors hamper economic growth. On the other hand organized crime may bring in considerable profits from criminal activities which by itself may give a boost to the economy. This result should not lead to the conclusion that up to a certain point organized crime can be beneficial for national economies. The overall net effect of organized crime on the economy through the paths of weakened governance and rampant corruption, is strongly negative (see Fig. 4 above).

The finding that on balance significant revenues from drugs trafficking or other forms of lucrative crime slow down rather than strengthen economic growth may seem paradoxical or surprising on first sight. But this phenomenon is actually just another example of what development economists have called the 'resource curse' (McMillan 2005). As mentioned above, developing countries that are rich in natural resources such as oil or diamonds often experience reduced rather than enhanced economic growth. This is because their institutions are undermined by rampant corruption at the highest level of government. Some of the main drugs exporting countries seem to suffer from exactly the same predicament. In such countries drugs generate by far the most profitable opportunities for 'rent seeking' by corrupt officials (Reuter et al. 2004). While corrupt elites accumulate great personal wealth, their countries remain underdeveloped and poor.

\section{In conclusion}

In this article we have used a newly designed index of organized crime for an explorative analysis of the interrelations between organized crime, law enforcement, rule of law and economic development. According to our findings, a political

\footnotetext{
${ }^{10}$ Analyses using the same indices that were used in the multiple regression analysis would have yielded very similar results. The fact that the use of different indicators of the key variables has little effect on the results of the analysis shows these results to be robust.

${ }^{11}$ An alternative path model which puts rule of law as the first independent variable and organized crime and corruption as intermediary variables shows very similar results. Rule of law is positively related with GDP both directly and indirectly through its impact on corruption. Rule of law is inversely related to organized crime which itself is positively related to GDP.
} 


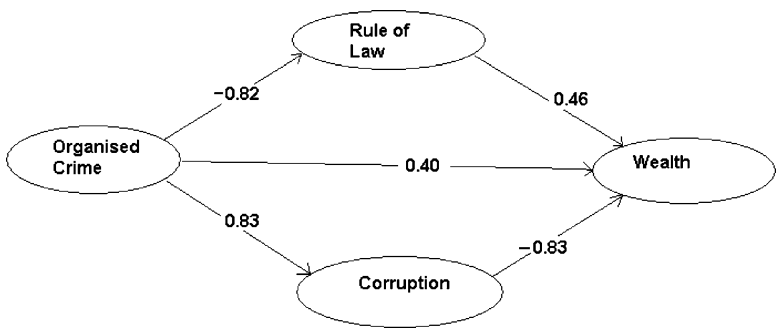

Fig. 5 Results of a structural model of the relationships between the prevalence of organized crime, rule of law and corruption and country wealth

strategy of tolerating activities of local criminal groups in the hope of beneficial effects on the wealth of a nation, is unlikely to bring the expected results. Although some types of organized crime may bring in significant revenues, tolerating Mafiatype activities implies letting the Trojan horse of racketeering and grand corruption into the walls of government. The inevitable deleterious effects on law enforcement, justice-related and political institutions will impede sustainable development in the long run.

In our view, the most important negative effect of organized crime, offsetting all possible benefits, is its pernicious impact on governance. Organized crime tends to erode the integrity of those holding a public office, including those responsible for upholding the rule of law. Where organized crime groups are powerful, legislation, policy-making and legal rulings no longer serve the general interest but the interests of the few. Through the pervasive bias of legislation, policy decisions and jurisprudence, market efficiencies are undermined and both local and foreign investors lose confidence in the legal and regulatory functions of the state and consequently stay away. A national growth strategy based on tolerating organized crime, is not just immoral but economically self defeating. Under such policies no country will ever achieve sustainable development. Many forms of organized crime such as drugs trafficking and illegal gambling are regarded as "victimless crimes". Although such crimes do not directly victimize individual persons, their overall impact on society constitutes a grave form of collective victimization. In studies of the costs of crime these indirect costs of organized crime at the collective level should be given more attention (Cohen 2000).

Case studies of individual countries/territories as varied as the USA (New York), Singapore, Botswana, Jordan, Hong Kong, South Africa and Taiwan document the crucial role of proper legal infrastructures and zero tolerance for organized crime and corruption in promoting economic growth (see e.g. the case studies of New York in Jacobs 1999, and of Taiwan in Lintner 2002). In Chile, one of the economically best performing countries in the region, a full-fledged ministry is tasked with the protection of the interests of the state (Szczaranski 2002). In light of our analytical findings such sustained investments in the control of organized crime-corruption seem to pay off handsomely. In countries where the establishment of strong law enforcement and justice institutions seems a feasible option, capacity building in these sectors qualifies as a uniquely cost effective development strategy. 


\section{References}

Acemoglu D, Johnson S (2003) Unbundling institutions. Working Paper, MIT, July 2003. Also in: The Journal of Political Economy 79:5. http://papers.ssrn.com/abstract

Barro RJ, Sala-i-Martin X (2004) Economic growth, 2nd edn. MIT Press, Cambridge, MA

BEEPS (1996) Business Environment and Enterprise Performance Survey. World Bank and the EBRD. http://info.worldbank.org/governance/beeps 1996

Brunetti A, Kisunko G, Weder B (1997) Institutional obstacles for doing business. Data description and methodology of a worldwide private sector survey. World Bank Policy Research Working Paper No. 1759. The World Bank, Washington, DC

Buscaglia E, Van Dijk J (2003) Controlling organized crime and corruption in the public sector. In: Forum on crime and society, vol III, no. 1 \& 2. United Nations Publication

Cohen MA (2000) Measuring the costs and benefits of crime and justice. In: Measurement and analysis of crime and justice, vol 4. Criminal Justice 2000, National Institute of Justice, July 2000

Eiras AI (2003) Make the rule of law a necessary condition for the millennium challenge account. In: The heritage foundation backgrounder. Washington, DC (7 March)

Feld LP, Voigt S (2003) Economic growth and judicial independence: cross country evidence using a new set of indicators. Eur J Polit Econ 19:497-527

Fijnaut C, Paoli L (2004) Organized crime in Europe. Concepts, patterns and control policies in the European union and beyond. Studies on Organized Crime, vol 4. Springer, Dordrecht, The Netherlands

Gastrow P (2003) Penetrating state and business. Organized crime in southern Africa, vol one. Institute for Security Studies, Pretoria

Giuliani RW (2002) Leadership. Talk Miramax Books, New York

Gonzalez-Ruiz S (2001) Fighting drug cartels on the Mexico-United States border. Forum Crime Soc $1: 19-31$

Hung-En Sung (2004) State failure, economic failure, and predatory organized crime: a comparative analysis. J Res Crime Delinq 41:111-129

Jacobs JB (1999) Gotham unbound: How New York city was liberated from the grip of organized crime. New York Univeristy Press

Johnson S, Kaufmann D, Zoido-Lobatón P (1998) Regulatory discretion and the unofficial economy. Am Econ Rev 88:387-392

Joly E (2003) Est-ce dans ce monde-là que nous voulons vivre? Editions des Arènes, Paris

Kangaspunta K, Joutsen M, Ollus N (1998) Crime and criminal justice in Europe and N. America 1990-1994. HEUNI, Criminal Justice Press, New York

Kaufmann D (2004) Governance redux: the empirical challenge. In: Sala-i-Martin X (ed) World Economic Forum. The global competitiveness report 2003-2004. Oxford University Press, New York

Kaufmann D, Kraay A (2002) Growth without governance. Economia 3:169-215. http://www.worldbank. org/wbi/governance/pubs/growthgov.html

Kaufmann D, Kraay A, Mastruzzi M (2003) Governance matters III: governance indicators for 1996-2002. Policy Research Working Paper 3106. World Bank, Washington, DC. http:/www.worldbank.org/wbi/ governance/pubs/govmatters3.html

Kenney DJ, Finckenauer JO (1995) Organized crime in America. Belmont: Wadsworth Publishing Compny

Knack S, Keefer P (1995) Institutions and economic performance: cross-country tests using alternative institutional measures. Econ Polit 7:207-227

Kury H (2001) International comparison of crime and victimization: the ICVS. International Studies in Social Science, vol 2. De Sitter Publications, Willowdale, Canada

Lambsdorff J (2004) How corruption affects economic development. Global corruption report 2004. Pluto Press, London

Lambsdorff J (2006) Measuring corruption-the validity and precision of subjective indicators (CPI). In: Sampford C et al. (eds) Measuring corruption. Ashgate Publishing, Aldershot, England

Levi M (2002) The organization of serious crime. In: Maguire M, Morgan R, Reiner R (eds) Oxford handbook of criminology. Oxford University Press, Oxford

Lintner B (2002) Blood brothers. Crime, business and politics in Asia. Allen \& Unwin, Crows Nest

Lynch JP (2006) Problems and promise of victimization surveys for cross-national research. Crime and justice, vol 34. University of Chicago, Chicago 
Mauro P (1996) The effects of corruption on growth, investment, and government expenditure. IMF working paper, September 1996

McMillan J (2005) "The main institution in the country is corruption": creating transparency in Angola. CDDRL, Stanford Institute of International Studies, Number 36

Merchant International Group Ltd (MIG) (2004) Grey area dynamics, organised crime figures 2004: special analysis for UNICRI Turin

Nieuwbeerta P (2002) Crime victimization in comparative perspective. Results from the International Crime Victims Survey, 1989-2000. Boom Juridische uitgevers, The Hague

Orlando L (2001) Fighting the mafia and renewing Sicilian culture. San Francisco: Encounter Books

Reuter P et al (2004) Mitigating the effects of illicit drugs on development. Potential roles for the World Bank. Rand Corporation project memorandum series. PM-1645-PSJ-1. Prepared for the World Bank

Shaw M (2003) Crime as business, business as crime. West African criminal networks in Southern Africa, SAIIA, Johannesburg (www.wits.ac.za/saiia)

Shaw M, Van Dijk J, Rhomberg W (2003) Determining global trends in crime and justice: an overview of results from the United Nations surveys of crime trends and operations of criminal justice systems. In: Forum on crime and society, vol III, no. $1 \& 2$

Szczaranski C (2002) Testimonios, el bisel del espejo: Mi ventana. Editorial Don Bosco S.A. Edebe, Santiago de Chile

Tornstensson J (1994) Property rights and economic growth: an empirical study. Kyklos 47:231-247

United Nations (1999) Global report on crime and justice. In: Newman G (ed) United Nations Office for Drug Control and Crime Prevention, Centre for International Crime Prevention. Oxford University Press, New York

United Nations Office on Drugs and Crime (UNODC) (2004) World drug report. New York

United Nations Office on Drugs and Crime (UNODC) (2005) World drug report. Vienna

Van Dijk JJM (2007) The world of crime; breaking the silence on problems of security, justice and development across the world. Sage, Thousand Oaks, CA

Van Dijk JJM, Nevala S (2002) Intercorrelations of crime. In: Nieuwbeerta P (ed) Crime victimization in international perspective. The Hague: Boom

Van Dijk JJM, Terlouw GJ (1996) An international perspective of the business community as victims of fraud and crime. Secur J 7:157-167

Van Dijk JJM, Mayhew P, Killias M (1990) Experiences of crime across the world: key findings from the 1989 International Crime Survey. Kluwer Law and Taxation Publishers, Deventer

von Lampe K (2004) Measuring organized crime: a critique of current approaches. In: Van Duyne PC, Jager M, Von Lampe K, Newel J (eds) Threats and phantoms of organised crime, corruption and terrorism. Wolf Legal Publishers

Waller I (2006) Less law, more order. The truth about reducing crime. Praeger, Westpoint

World Bank (2005) World development report: doing business in 2005. Washington, DC

World Economic Forum (2003) The global competitiveness report 2002-2003. Oxford University Press, New York

World Economic Forum (2004) The global competitiveness report 2003-2004. Oxford University Press, New York

World Tourism Organization (1997) Tourist safety and security: practical measures for destinations. Madrid

Zhang X (2001) The emergence of 'black society' crime in China. Forum Crime Soc 1:53-73 